\title{
IN MEMORIAM \\ GUDRUN VUILLEMIN-DiEM \\ (16.I.1931-16.XI.2018)
}

\author{
PIETER BEULLENS \\ UNIVERSITY OF LEUVEN
}

Gudrun Vuillemin was born under the name Diem on 16 January 1931 in Berlin. In her youth she saw the rise of the Nazi regime in the capital, and its eventual downfall. These events brought her and her family to post-war Cologne. She read philosophy, mathematics, and German philology at the local university. Her dissertation on Nietzsche's concepts of art was published in $1953 .{ }^{1}$

After the completion of her $\mathrm{PhD}$, she became the first collaborator at the newly established Husserl-Archive in Cologne, where she seemed to have made an overwhelming impression on its director Walter Biemel. He describes her as "die kluge, bildhübsche und elegante Gudrun Diem », only to regret that she soon left to be employed at the Thomas-Institute. ${ }^{2}$

There, she was involved in the preparation and publication of virtually all volumes that appeared in the seventies and eighties of the Miscellanea Mediaevalia series, the proceedings of the yearly "Kölner Mediaevistentagung ». Since her wedding with the famous French philosopher Jules Vuillemin in 1967, the volumes she edited for this series and her other works came out under her married name.

Useful though her role in the Miscellanea Mediaevalia was, her most important contribution to the study of medieval philosophy lies in philological work. The eminent director of the Aristoteles Latinus series and Oxford professor Lorenzo Minio-Paluello had noticed the recognizable talents of the young scholar - who incidentally had no formal academic training in Greek nor Latin! -, and convinced her superiors in Cologne, first Paul Wilpert and later Albert Zimmermann, to allow her to work on the edition project. Minio-Paluello guided
\end{abstract}

GUDRUN Diem, Das Wesen der Kunst im Denken Nietzsches, Hofmann, Schorndorf 1953.

Walter Biemel, «Zur Gründung des Kölner Husserl-Archives. Die Bedeutung eines Traumes », Studia Phaenomenologica, 1 (2001), p. 39-61, quote on p. 57-58. 
Pieter Beullens

her towards the intricate tradition of the twelfth- and thirteenth-century GreekLatin translations of the Metaphysica, arguably the most widely read and studied Aristotelian treatise in the medieval period. A warm and lasting friendship based on mutual admiration developed, and Vuillemin-Diem valued his opinion until his death in 1986.

A really Herculean labour awaited Vuillemin-Diem: hundreds of medieval manuscripts were known to contain the Metaphysica, but there was no assessment of what the exact content of each copy was, as various Latin translations circulated and their transmissions were intertwined. Her efforts resulted in a first publication in 1970, which contained two partially preserved Latin versions, both stemming from the work of James of Venice in the first half of the twelfth century. ${ }^{3}$ Six years later, the edition of a somewhat younger, anonymously transmitted translation appeared in print. ${ }^{4}$

The most challenging edition became her master piece. For the version made by William of Moerbeke in the middle of the thirteenth century she succeeded in identifying the various successive stages of his work. Part of Moerbeke's text was based on a copy of the previous translation, which he revised to fit his standards and complemented with a new translation by his own hand for the missing sections. ${ }^{5}$ To unambiguously inform the readers of the complicated affairs within the text, Vuillemin-Diem developed a distinctive set of typographical indications that could guide them through the information contained in text and apparatuses. Although it met with serious opposition from the director of the series, Gerard Verbeke, she stuck to her concept, which eventually became the standard style sheet for editions of similarly transmitted texts.

Other aspects of Moerbeke's translation where Vuillemin-Diem's edition proved groundbreaking were her identification of the Greek manuscript that he had used as his main model, and the extremely detailed analysis of the text's transmission process in university circles in late-medieval Paris.

With the completion of these editions her academic career came to an end: she officially retired from the Thomas-Institute, but remained in very active service. By now, she had mastered William of Moerbeke's style and working method to perfection. This resulted in a further brilliant study and critical edition of his Meteorologica translation. ${ }^{6}$ Here too, she discovered several

3 Gudrun Vuillemin-Diem (ed.), Metaphysica. Lib. I-IV.4. Translatio Iacobi sive 'Vetustissima' cum scholiis et Translatio Composita sive 'Vetus', Desclée De Brouwer, Bruxelles-Paris 1970 (Aristoteles Latinus, $\left.251-1^{a}\right)$.

4 EAD., Metaphysica. Lib. I-X, XII-XIV. Translatio Anonyma sive 'Media', Brill, Leiden 1976 (Aristoteles Latinus, 25 2).

5 EAD., Metaphysica. Lib. I-XIV. Recensio et Translatio Guillelmi de Moerbeka, 2 vols., Brill, Leiden - New York - Köln 1995 (Aristoteles Latinus, 25 3.1-2).

6 EAD., Meteorologica. Translatio Guillelmi de Morbeka, 2 vols., Brepols, Turnhout 2008 (Aristoteles Latinus, 10 2.1-2). 
chronologically different layers, and followed the translator's decisions through the traces that he had left in his Greek model manuscript.

She was certainly pleased that for her editions of Moerbeke translations, the series' editorial board no longer required the use of Latin in the prefaces. In her own German mother tongue she was able to take the reader along the discoveries she had made during her editorial work and the hypotheses that resulted from it. she wrote in a very didactic and detailed way, wanting to share her train of thoughts and subjecting it to the reader's judgement. Her inclination to full disclosure of her editorial decisions resulted in extensive prefaces, which for both editions had to be confined to separate volumes. They unquestionably form models of critical analysis and its reporting.

Her struggle with the preparation of the Latin prefaces in the earlier volumes had revealed a significant feature of her character. In a letter to Lorenzo MinioPaluello, whom she always kept up to date on the progress she made on the Aristoteles Latinus editions, she wrote that a Latinist colleague was helping her to bring the language of her preface to more classical level. To her mentor she admitted that she wanted to limit his interventions to a minimum: "ich will sagen können, daß ich den Teil selbst in Latein geschrieben habe ». ${ }^{7}$ VuilleminDiem was not one to shy away from a challenge, however daunting the task ahead appeared to be.

It was not the quest for personal glory that drove her in her endeavours, yet she particularly valued the opinion and the appraisal of her academic peers. Deep within her, she struggled to overcome the fear that her work somehow would not meet with the expected standards or be open to criticism. In the light of the exemplary editions that she later produced, Minio-Paluello did not strike the right tone when he reassured her that the work she had submitted to him was good enough for publication, «if the Aristoteles Latinus texts are to appear before our generations have passed, and the interest in these things have vanished $» .^{8}$

The author of the present obituary remembers how she had a long phone call about another project - this would be her final one, she pledged! - that she wanted to embark upon. Fernand Bossier, whose work she particularly valued, had not been able to finish the edition of Ptolemy's Tetrabiblos in the translation by William of Moerbeke, which he had identified together with his student Luc Anthonis. Would she be able to meet with Bossier's intended aims, and would she herself see it finished? After our call - and there must have been many others! -

7 Letter to Lorenzo Minio-Paluello, undated, likely January 1976 (underlining from the original typoscript). Copies and drafts of her correspondence with Minio-Paluello and others are preserved in the Aristoteles Latinus archive.

8 Letter from Lorenzo Minio-Paluello, dated 26 October 1967. 
Pieter Beullens

she decided to accept the challenge. She completed her last critical edition in collaboration with Carlos Steel and with the help of Pieter De Leemans in 2015. ${ }^{9}$

Even then, well within her life's ninth decade, she remained active and inquisitive, always looking for loose ends where she might be able to provide better, and often definitive, answers. It resulted in her last, posthumously published study with Fabio Acerbi, in which she unravels in great detail William of Moerbeke's use of a particular Greek manuscript, and meticulously paints the events concerning the papal library in the thirteenth century, from which it is one of the rare survivors. ${ }^{10}$ The book will be a lasting reference point, as are her previous publications about two translators from the twelfth century, and a commentator who lived in the next. Her article about Burgundio of Pisa's translation activity and his use of an important collection of Greek manuscripts forms an landmark in the field of translation studies. ${ }^{11}$ In her article of nearly monography length about David of Dinant she deconstructs the mysteries that had surrounded this scholar and proves beyond doubt that he was a gifted translator with a direct access to valuable Greek source texts. ${ }^{12}$ And her attribution of an anonymous commentary on Aristotle's Meteorologica to Mahieu le Vilain, who was previously only known as the author of a French translation of the text, opened up new aspects of the latter's learning. ${ }^{13}$

While Gudrun Vuillemin-Diem was so good in assessing the impact of others' work, in particular the late medieval translators', she was not able to fully appreciate the importance of her own output, as a fatalistic and slightly melancholic aside in a letter to Minio-Paluello documents: « und wenn man im Grabe liegt, dann interessiert es sowieso keinen mehr $»{ }^{14}$ On this particular point, history has proved her wrong: the stellar quality of her life's achievements set the standards which other editors of medieval Latin translations must aim for as their targets, in the modest awareness that they are unlikely to ever reach them.

9 Gudrun Vuillemin-Diem, Carlos Steel, Pieter De Leemans, Ptolemy's Tetrabiblos in the Translation of William of Moerbeke. Claudii Ptolemaei Liber Iudicialium, Leuven University Press, Leuven 2015 (Ancient and Medieval Philosophy, De Wulf-Mansion Centre. Series 1, 19).

10 Fabio Acerbi, Gudrun Vuillemin-Diem, La transmission du savoir grec en Occident. Guillaume de Moerbeke, le Laur. Plut. 87.25 (Thémistius, in De an.) et la bibliothèque de Boniface VIII, Leuven University Press, Leuven 2019 (Mediaevalia Lovaniensia. Series 1, Studia 49).

11 Gudrun Vuillemin-Diem, Marwan Rashed, « Burgundio de Pise et ses manuscrits grecs d'Aristote. Laur. 87.7 et Laur. 81.18 », Recherches de Théologie et Philosophie Médiévales, 64 (1997), p. 136-198.

12 GudRUn Vuillemin-Diem, «Zum Aristoteles latinus in den fragmenten der Quaternuli des David von Dinant », Archives d'histoire doctrinale et littéraire du Moyen Âge, 70 (2003), p. 27-136.

13 EAD., «Anonymus Normannus (Mahieu le Vilain): Super Meteora II.9-III. Identifizierung des Autors, zur Eigenart des Textes, mit einer Edition von zwei Kapiteln der noch unveröffentlichten Schrift », Recherches de Théologie et Philosophie Médiévales, 71 (2004), p. 1-130.

14 Letter to Lorenzo Minio-Paluello, dated 4 December 1978. 